DOI 10.4467/25439561KSR.19.008.11310

Elena Borisovna Lopatina (Jelena Borisovna Łopatina) Instytut Słowianoznawstwa Rosyjskiej Akademii Nauk Moskwa

\title{
ПОЛЬША НА ГЕОПОЛИТИЧЕСКОМ ПЕРЕПУТЬЕ: МЕЖДУ СССР И ЗАПАДНЫМИ СОЮЗНИКАМИ В 1943-1945 ГГ.
}

\author{
POLAND AT THE GEOPOLITICAL CROSSROADS: \\ BETWEEN THE USSR AND WESTERN ALLIES IN 1943-1945
}

Streszczenie

Artykuł poświęcony jest zewnętrznym warunkom politycznym, które odegrały ważną rolę w ustanowieniu geopolitycznego miejsca Polski w powojennym świecie. Na podstawie dokumentów ostatnio udostępnionych przeanalizowano strategię polskiego rządu w stosunkach z ZSRR 1943-1945 i zachodnimi sojusznikami. Położono akcent na wydarzenia, które odegrały kluczową rolę w kreowaniu wizerunku Polski po II wojnie światowej i uczynieniu z niej sojusznika ZSRR w czasie zimnej wojny.

\begin{abstract}
The article is focused on analysis of foreign policy factors that played prominent role in defying the geopolitical place of Poland after the Second World War. Foreign strategy of the Polish government is shown based on the newly introduced scientific archive sources, its main vector is analyzed. The author underlines the events that more than others contributed to forming the after-war political image of Poland which became a part of the Soviet camp in the cold war.
\end{abstract}

Słowa kluczowe: Polska w latach 1943-1945, ZSRR, sojusznicy zachodni Keywords: Poland in 1943-1945, the USSR, Western Allies

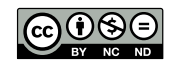


На исходе Второй Мировой войны решалось, каков будет социально-политический облик польского государства и изменятся ли послевоенные границы Польши. Не последнюю роль в решении этих вопросов сыграли внешние факторы: взаимоотношения между союзниками по антигитлеровской коалиции и внешнеполитическая деятельность польского правительства в Лондоне.

На наш взгляд, ключевые события 1943-45 гг,, которые сыграли решающую роль при определении послевоенного облика послевоенной Польши, были следующие: разрыв советско-польских отношений в апреле 1943 года; исход переговоров по польскому вопросу на Тегеранской мирной конференции; безрезультатность переговоров Миколайчика со Сталиным в октябре 1944 года, за чем последовала отставка Миколайчика; образование 21 июня 1944 года ПКНО (Польского Комитета Национального Освобождения) в Москве; оформление нового польского правительства и признание восточной границы Польши по линии Керзона.

Остановимся более подробно на каждом из перечисленных событий.

Разрыв советско-польских отношений произошел после того, как правительство Сикорского отреагировало на сообщение немецкой стороны от 13 апреля о найденных в Катыни останках польских офицеров, расстрелянных советскими властями в 1940 году ${ }^{1}$. Министры обороны и пропаганды «лондонцев» от имени польского правительства обратились 17 апреля в Международный Красный Крест с просьбой провести независимое расследование произошедшего, а польская эмигрантская пресса развернула по этому поводу шумную кампанию. С таким же обращением выступил и Берлин, пригласивший международных экспертов в Катынь. Красный Крест дал согласие на проведение подобного расследования ${ }^{2}$.

Итоговое сообщение Сталина о разрыве отношений с польским правительством 25 апреля в Лондоне и Вашингтоне было встречено с тревогой. С разрывом дипломатических отношений между СССР и польским правительством в Лондоне нельзя было исключать, что следующим шагом Сталина может стать создание нового, просоветского, польского правительства и одностороннее его признание. Этого не могли допустить союзники. Дальновидный и прагматичный политик, генерал Сикорский понимал разрушительные последствия разрыва отношений с СССР как внутри страны, так и на международной арене.

1 Подробнее см.: Лопатина Е. Б., Сталин-Сикорский-Черчилль: хронология разрыва советско-польских отношений в апреле 1943 года [в:] Материалы всероссийской научно-технической конференции (Воронеж, 11-12 мая 2017 года). Воронеж. 2017. С. 340-345.

2 О коммюнике польского правительства от 17.04 см. АВП РФ. Ф. 059. Оп. 10. Д. 51. Л. 213-210; Документы внешней политики СССР. 1943 Т. 26. Кн. 1. 2 января - 31 августа 1943 г. Майкоп 2016, с. 309 - 311. 
Он полагал, что Польша неминуемо войдет в сферу операций советских войск и выражал надежду, что отсутствие дипломатических отношений не продлится долго. ${ }^{3}$

На наш взгляд, разрыв отношений с Польским правительством произошел не потому, что это было частью плана советского правительства с тем, чтобы впоследствии избавиться от партнерства с несговорчивым лондонским правительством, а потому, что польское правительство заняло уязвимую позицию - фактически приняло немецкую версию событий. Это позволило Сталину поставить точку в отношениях с неудобным партнером, ведь Сикорский отказался обсуждать предложение Сталина о восточной границе Польши по линии Керзона.

На конференции глав великих держав 28 ноября - 1 декабря 1943 г. в Тегеране обозначились долгосрочные интересы и позиции членов антигитлеровской коалиции, в том числе по польскому вопросу. Английский премьер-министр посчитал обоснованным предложение Сталина по восточной границе Польши и согласился с идеей о том, что территориальные интресы Польши можно удовлетворить за счет Гремании ${ }^{4}$. Что интересно, в Тегеране польский вопрос обсуждался без присутствия польского премьера, и это фактически шло вразрез с договоренностями польской стороны с Черчиллем.

Как показывают документы, проблема польского партнера не только в двусторонних отношениях, но и в «треугольнике» великих держав оставалась для Москвы очень важной. Советское руководство пришло к выводу, что политики, представленные в «лондонском» правительстве Польши, не готовы установить нормальные отношения с СССР. Реагируя на «нажим» партнеров по коалиции 27 февраля, Сталин отвечал Рузвельту 3 марта 1944 г.: «Приходится констатировать, что решение о советско-польских отношениях не назрело» ${ }^{5}$.

Сталину нужны были представительные силы в Польше, с которыми могли бы иметь дело советские войска, когда пересекут этнографическую границу Польши, чтобы не устанавливать оккупационный режим. В июне 1944 года Миколайчик беседовал с советским послом о советских условиях признания лондонского правительства, и советские условия были таковы: установление

3 См.: Заявление польского правительства о решении советского правительства прервать дипломатические отношения с польским правительством. Armia Krajowa w dokumentach. 19391945. T. II. Wrocław-Warszawa-Kraków, 1991. S. 508-509.

4 Запись четвертого пленарного заседания 1 декабря 1943 года [в:] Тегеранская конферениия руководителей трёх держав СССР, США и Великобритании (28 ноября-1 декабря 1943 г.). Москва, Политиздат 1978. С. 165-167.

5 Переписка Председателя Совета Министров СССР с президентами США и премьер-министрами Великобритании во время Великой Отечественной войны 1941-1945. Т. II. М., 1957. С. 127. 
восточной границы Польши по линии Керзона, удаление из польского правительства тех министров, которые были инициаторами расследования Красного Креста о Катынских событиях. Миколайчик не дал ответа по этим вопросам, что подстегнуло формирование ПКНО: в ночь с 21 на 22 июля 1944 г. в кабинете Сталина были согласованы персональный состав ПКНО и окончательный текст его Манифеста, в основе которого лежали документы ПНК, просмотренные и одобренные Сталиным еще в апреле 1944 г.

ПКНО был создан в Москве, и до 26 июля оставался там же. Отпечатанный Манифест «К польскому народу» самолетом доставили в освобожденный польский город Хелм - резиденцию нового «законного, но временного органа исполнительной власти». 22 июля 1944 г. Манифест ПКНО был обнародован и оглашен по московскому радио. Документ был призван стать политической платформой, вокруг которой можно было бы объединить разные социальные слои общества для участия в борьбе за разгром гитлеровской Германии и создание государства в новых границах. При этом, как отмечал Сталин в письме Черчиллю, ПКНО - это лишь комитет, а не новое польское правительство ${ }^{6}$.

Летом 1944 года польское правительство в Лондоне предприняло попытку закрепить независимую линию поведения в международных делах и инициировало начало освобождения Варшавы силами Армии Крайовой - Варшавское восстание, которое продолжалось с 1 августа по 2 октября 1944 года.

Слабо поддержанное Великобританией и США, политически направленное против СССР, восстание потерпело поражение, поскольку немецкое командование не собиралось сдавать Варшаву, а восставшие не обладали достаточными ресурсами для полного осовбождения города своими силами. Восстание стало предвестником краха того геополитического проекта, который был создан в довоенной Польше. Цель этого проекта состояла в том, чтобы Польша стала лидером малых государств восточноевропейского региона в новом формате «малой Антанты», превратилась в важный геополитический фактор для западных союзников, обрела ключевую роль в противостоянии Советскому Союзу. Польское правительство было убеждено, что если не в военном смысле, то в геополитическом, Советский Союз потерпит поражение, однако восстание задохнулось, и попытка реализовать этот проект привела к тому, что лондонское правительство оказалось в слабой и уязвимой позиции ${ }^{7}$.

6 Переписка Сталина с Рузвельтом и Черчиллем в годы Отечественной войны. М. 2017. Т. 1. C. 503-504.

7 См.: Советский Союз и польское военно-политическое подполье, апрель 1943-декабрь 1945 г2. Варшавское восстание, июль-ноябрь 1944 г. Сборник документов в 3-х томах. Т. 2. Ч. 1. Отв. Ред. Артизов А. Н. М. 2016. 
Следующий этап в определении геополитической позиции Польши - октябрьские переговоры в Москве в 1944 году в рамках четвертой Московской конференции. Стоит отметить, что во время октябрьских переговоров между Черчиллем и Сталиным Миколайчик также находится в советской столице. Черчилль приезжает в Москву, чтобы обсудить два главных вопроса: 1) договориться о сферах влияния в послевоенной Европе: распределить в процентном соотношении влияние СССР и западных держав в сопредельных странах ${ }^{8} ; 2$ ) попытаться ещё раз оказать давление на Миколайчика, чтобы он уступил по вопросу о восточной границе по линии Керзона. Миколайчик в целом склонялся к тому, чтобы принять условия Сталина по восточной границе ${ }^{9}$, но, будучи премьером, должен был посоветоваться с правительством для принятия окончательного и легитимного решения. В Лондоне же позиция Миколайчика, склонного уступить давлению Черчилля и Сталина, встречает жесткую оппозицию, и 24 ноября польский премьер отправлен в отставку, вместо него главой лондонского правительства становится Арцишевский.

Невозможность прийти к договоренности по восточной границе между лондонским правительством и Сталиным, противоречия по ряду других военно-политических вопросов открыло путь для преобразования ПКНО во временное правительство, что и произошло в новогоднюю ночь с 1944 на 1945 год. При этом показательно, что на 2/3 новое правительство состояло из членов ПКНО, а $1 \backslash 3$ состава нового правительства - это демократические деятели польской диаспоры из-за рубежа (США и Великобритании). ${ }^{10}$ Такой смешанный состав правительства был необходим, чтобы добиться определенного компромисса между просоветскими и антисоветскими силами и в тоже время узаконить власть правительства, в целом лояльно настроенного по отношению к восточному соседу.

Возглавить новое правительство было предложено Миколайчику, поскольку оно не должно было выглядеть слишком просоветским, и фигура Микола-

8 Такая договоренность была достигнута во время четвертой Московской конференции в октябре 1944 года. Согласно соглашению, общей сферой влияния СССР и западных союзников должны были стать Югославия и Венгрия, Румыния и Болгария - сферой влияния СССР, Греция - Великобритании и США. Оригинал записки с договоренностью Черчилля и Сталина о разделе Юго-Восточной Европы на сферы влияния, получившей название «соглашение о процентах», был представлен в Национальном архиве Великобритании в рамках выставки о холодной войне в апреле 2019 года.

9 См. Observations of the Polish Prime Minister on the situation of Poland in connection with the Moscow Conference held in October, 1944. PISM (Polish Institute and Sikorski museum). PRM. Z. 5. P. 35-36

10 Споры между союзниками о принципах формирования нового правительства Польши прослеживаются по документам, например: Documents on Polish-Soviet relations. 1939-1945. Vol. II: 1943-1945. London, 1967. P. 416-422. 
йчика как представителя крестьянской партии, бывшего премьер-министра лондонского правительства, была очень важна. Однако Миколайчик отказался возглавить правительство, и тогда было предложено включить Миколайчика как вице-премьера при условии, что он публично признает восточную границу Польши по линии Керзона. В апреле 1945 года это признание было сделано, и Миколайчик получает пост вице-премьера в новом правительстве.

Даже и на следующей конференции «большой тройки» - на Ялтинской конференции - вопрос о границах Польши так и не был решен. В Крыму особенно острые споры были о западной границе, в том числе о принадлежности Нижней Силезии (Правобережье Одера вплоть до правобережья Западной Нейсе).

Рузвельт отметил, что: «Делегация США согласна с предоставлением Польше компенсации за счет Германии, а именно Восточной Пруссии к югу от Кенигсберга и Верхней Силезии вплоть до Одера. Однако Рузвельт отметил, что перенесение польской границы на Западную Нейсе мало оправданно, с его точки зрения» ${ }^{11}$.

Вопрос «компенсации территориальных потерь» Польши за счёт Германии вызвал весьма резкий протест британского премьера. Черчилль с жаром доказывал, что, отрывая от немцев огромный кусок земли, союзники спровоцируют рост реваншистских настроений даже в разделённой послевоенной Германии.

Сталин предлагал отдать Польше Нижнюю Силезию и балтийское побережье - часть Восточной Пруссии и Поморье с городом Гданьск (Данциг). Черчилль не согласился с этими предложениями.

В феврале 1945 года стороны так и не сумели прийти к общему знаменателю по поводу послевоенных размеров польского государства. И пока «бесспорная» территория Польши составляла 212 тысяч квадратных километров (современная площадь Польши - 312 км кв.) 21 апреля 1945 года СССР подписал с временным правительством Польши договор о дружбе. СССР не стал ждать «благословения» Лондона и Вашингтона и, воспользовавшись тем, что эти территории и так были под его контролем, отдал полякам в управление принадлежащие Германии территории в Поморье и Силезии площадью в 100 тысяч квадратных километров. Так благодаря позиции Советского Союза по вопросу о границах территория Польши «явочным порядком» выросла на треть.

На Потсдамской конференции, проходившей с 17 июля по 2 августа 1945 года, предложения Сталина по Польше были утверждены: территория Польши

${ }^{11}$ Крымская конференция руководителей трех союзных держав - СССР, США и Великобритании (4-11 февраля 1945 г.) [в:] Сер. Советский Союз на международных конференциях периода Великой отечественной войны, 1941-1945 г2. Сборник документов. - Т. 4. - М.: Политиздат, 1984. С. 302. Крымская конференция. 4-11 февраля 1945 г. Запись заседания глав правительств. 8 февраля 1945 г., 16 час., Ливадийский дворец. 
усекалась вследствие потери земель к востоку от линии Керзона, но расширялась за счет присоединения бывших немецких земель за западе. Учитывая то, что ещё в феврале 1945 года союзники признали враждебность польского военно-политического подполья ${ }^{12}$, а это дало советскому руководству право на подавление подполья, связанного с лондонским правительством, геополитический поворот послевоенной Польши в сторону СССР становился все более явным.

Итак, в силу ряда внешнеполитических обстоятельств, вследствие шагов польского правительства в Лондоне, действий советского правительства и взаимодействия лидеров «большой тройки», после войны на западных границах СССР возникла не враждебная, а дружественная просоветская Польша.

\section{Библиография}

Armia Krajowa w dokumentach. 1939-1945. T. II. Wrocław-Warszawa-Kraków. 1991.

Documents on Polish-Soviet relations. 1939-1945. Vol. II: 1943-1945. London, 1967.

Skrzypek A. Mechanizmy uzależnienia. Stosunki polsko-radzieckie. 1944-1957. Pułtusk, 2002.

Лопатина Е. Б., Сталин-Сикорский-Черчилль: хронология разрыва советско-польских отношений в апреле 1943 года [в:] Материалы всероссийской научно-технической конференции (Воронеж, 11-12 мая 2017 года). Воронеж. 2017.

Носкова А.Ф. Геополитические планы СССР и трагедия Армии Крайовей // Studia Polonica. К 90-летию И.И. Костюшко. М. 2009.

Парсаданова В.С. Советско-польские отношения. 1945-1949. М. 1990.

Переписка Председателя Совета Министров СССР с президентами США и премьер-министрами Великобритании во время Великой Отечественной войны 1941-1945. Т. II. М. 1957.

Переписка Сталина с Рузвельтом и Черчиллем в годы Отечественной войны. T. 1. M. 2017.

12 См. Подробнее: Skrzypek A. Mechanizmy uzależnienia. Stosunki poklsko-radzieckie. 19441957. Pułtusk, 2002. S. 95-101; Парсаданова В.С. Советско-польские отношения. 1945-1949. М., 1990. С. 85-92; Носкова А.Ф. Геополитические планы СССР и трагедия Армии Крайовей // Studia Polonica. К 90-летию И.И. Костюшко. М., 2009. 
Советский Союз и польское военно-политическое подполье, апрель $1943-$ декабрь 1945 гг. Варшавское восстание, июль-ноябрь 1944 г. Сборник документов в 3-х томах. Т. 2. Ч. 1. Отв. Ред. Артизов А. Н. М. 2016.

Тегеранская конференция руководителей трёх держав СССР, США и Великобритании (28 ноября - 1 декабря 1943 г.). М. 1978.

\section{References}

Armia Krajowa w dokumentach. 1939-1945. T. II. Wrocław-Warszawa-Kraków. 1991.

Documents on Polish-Soviet relations. 1939-1945. Vol. II: 1943-1945. London, 1967.

Skrzypek A. Mechanizmy uzależnienia. Stosunki polsko-radzieckie. 1944-1957. Pultusk, 2002.

Lopatina E. B., Stalin-Cikorskij-Cherchill': hronologija razryva sovetsko-pol'skih otnoshenij v aprele 1943 goda [B:] Materialy vserossijskoj nauchno-tehnicheskoj konferencii (Voronezh, 11-12 maja 2017 goda). Voronezh. 2017. C. 340-345.

Noskova A.F. Geopoliticheskie plany SSSR i tragedija Armii Krajovej // Studia Polonica. K 90-letiju I.I. Kostjushko. M. 2009.

Parsadanova V.S. Sovetsko-pol'skie otnoshenija. 1945-1949. M. 1990.

Perepiska Predsedatelja Soveta Ministrov SSSR s prezidentami SShA i prem'erministrami Velikobritanii vo vremja Velikoj Otechestvennoj vojny 1941-1945. T. II. M. 1957.

Perepiska Stalina s Ruzvel'tom i Cherchillem v gody Otechestvennoj vojny. T. 1. M. 2017.

Sovetskij Sojuz i pol'skoe voenno-politicheskoe podpol'e, aprel' 1943-dekabr' 1945 gg. Varshavskoe vosstanie, ijul'-nojabr' 1944 g. Sbornik dokumentov v 3-h tomah. T. 2. Ch. 1. Otv. Red. Artizov A. N. M. 2016.

Tegeranskaja konferencija rukovoditelej trjoh derzhav SSSR, SShA i Velikobritanii (28 nojabrja - 1 dekabrja 1943 g.). M. 1978. 